\title{
Determining the Turkish World Perceptions of Candidate Social Studies Teachers through Word Association Test ${ }^{i}$
}

\author{
Halil Tokcan \\ Department of Education, Niğde Ömer Halisdemir University, Turkey
}

Copyright $\subset 2017$ by authors, all rights reserved. Authors agree that this article remains permanently open access under the terms of the Creative Commons Attribution License 4.0 International License

\begin{abstract}
The purpose of this study is to observe prospective teachers' cognitive structures related to Turkish World. In this scanning model study, WAT (Word Association Test) had been applied to 332 prospective teachers in Niğde Ömer Halisdemir University. And they were asked to write what comes into their heads when it is said Turkish Republics and Turkish World. Words were given to the prospective teachers. According to the research, 'Turk' is the only common Word which is related to the concept of six independent Turkish Republics and Turkish World. There is no any other common word except this, perceived by prospective teachers. Students generally independent Turkish Republic and Turkey they do not have a lot of information and perceptions about the world; they know the general concept of popular culture, it said they did not know specific concepts or people belonging to the country. Independent of the Turkish states K.K.T.C. It has become the most irrelevant and disconnected with other countries. K.K.T.C. with the only common link between other countries "Turkey" was the word. Students are most perceptive grasp of Azerbaijan, while country-owned; they have been gripping the country at least perceptually Uzbekistan.
\end{abstract}

Keywords Teacher Candidate, Word Association Test, Turkish World, Turkish Republics

\section{Introduction}

In parallel with the increasing effectiveness of the constructivist learning approach in the educational settings in recent years, there have been radical changes in the understanding of evaluation-assessment accordingly. Traditional techniques, which are on a simple level, superficial and have a single true response to, have been replaced by alternative techniques that measure deeper, more meaningful and conceptual knowledge. Alternative evaluation-assessment techniques were emphasized even further in the new elementary programs renewed and introduced in 2005 [1].

It is considered important in the alternative understanding of evaluation-assessment to assess an interconnected, well-constructed map of knowledge instead of independent and incoherent pieces of knowledge [1]. There are several techniques serving this purpose (Concept Maps, Mind Maps, Constructed Grid, Diagnostic Branched Tree, etc.). One of those techniques is the Word Association Test (WAT). Word association test (WAT) is an alternative evaluation-assessment that helps observing student's cognitive structure, the connection with the concept that forms this structure and the map of knowledge constructed in the mind and determining whether the inter-conceptual connection in the long-term memory is well-constructed or that connection is significant $[2,3,4]$. Word association test (WAT), for example, indirectly investigates the student's knowledge structure, providing wide-ranging lists of words that are associated with a key (stimulus) concept in the student's mind [5].

5 to 10 key concepts are selected in regard to any topic when preparing the word association test. These selected concepts are written as a list for 10-15 times to fill up a full page. The first page includes the instructions of application and the second page provides an example. Students are required to write down concepts reminded by the key concept in 30 seconds. Teacher decides when students will pass on the next key concept. It is important that each concept is arranged in such a way that it will not be seen in successive pages. This aims at preventing the risk of writing words as chain responses. Indeed, if students do not go back to the key concept when writing down each word, they may write down the words reminded by the concept they have written down instead of the key concept. This hurts the purpose of the test. After students have responded to all the keywords, the word association tests are collected and evaluated by the teacher $[6,7,8]$.

The word association test can also be used as a diagnostic tool and an assessment tool. Applied as a pretest in the beginning of the class, the word association test is applied at the end of the subject and the results of both tests are 
compared. By this means, changes and conceptual developments are monitored among students [9].

The evaluation of the word association technique (WAT) can be performed in two ways: in the first evaluation, scoring can be taken as a basis. If the word written down by the student for the key concept consists of the correct response, it is awarded with one point and the test score is calculated. The teacher may ask the student to write down a sentence to control if the response given is meaningful. The sentence written down by the student can be also rewarded with one point separately. In the second evaluation, a frequency table was prepared to show how many times, and which words and concepts were repeated in response to a key concept. A map of concept can be established through the frequency table to see the cognitive structure and the conceptual connections. The breakpoint technique suggested by Bahar, Johnstone and Sutcliffe (1999) is used to create a concept map. While the upper part of the highest frequency above the breakpoint created forms the schema in the first part of the concept map, the concept map will be created when all the words constituting the whole key concept appear on the concept map as the breakpoint is lowered periodically. In this technique, a certain amount below the most frequently given response for any key concept in the word association test is used as the breakpoint. The responses above this response frequency are written down in the first part of the concept. Next, the breakpoint is lowered periodically and the process is continued until all the keywords appear on the concept map. Concepts appearing in each breakpoint range mean that they were repeated in the number of the students in that range. For example, concepts appearing in the 20-29 breakpoint range were stated by 20 to 29 students as response words. Such a concept map reveals how students see the relations between the concepts and leads to the discovery of new relations. The teacher can question his/her method by looking at this concept map and dwell on the missing concepts in the map again $[6,8]$.

Word association tests have been used for several different purposes. They have been used for different fields of learning in revealing students' cognitive structures [2-5; 8-32], detecting their misconceptions [3, 33] and determining their conceptual developments [34]. Yet, almost all of these studies were performed in the field of science (biology teaching, chemistry teaching, science teaching, etc.) And there has been no study observed in the literature that is performed with WAT to reveal students' perceptions on the Turkic world. Alım [35] detected the Geography Education students' perceptions of the Turkic World with the knowledge test and open-ended questions; Aksoy and Karaçalı [36] wanted to learn about seventh-grade students' perception of the Turkic World on their mind map by asking them to find those countries on the dummy map; and Topal and Sezer [37] found about university students' levels of awareness of the Turkic World geography with map and flag knowledge along with the open-ended questions. Other than these studies, Tuncel [38] tried to reveal students' perceptions of Islam in their minds by drawing a map; Bilgiç and Akyürek [39] examined Balkan-origin students' perceptions of Turkey in Balkans and the Turks; and Alkan [40] examined university students' perceptions of the European Union in Turkey. In Taşkaya's study [41] the perceptions and information levels of applicants of primary school teaching on Turkish World was examined. The study was carried out with 18 students studying in the 4th Grade of Main Scientific Branch "Primary School Teaching" of Ahmet Kelesoğlu Educational Faculty, Selcuk University. The data of the study was collected via open ended questionnaire, developed by researcher.

In his speech on the 29th October 1933, Mustafa Kemal Atatürk, the founder of the Republic of Turkey. Said: "Today, the Soviet Union is our friend; our neighbor and ally. We are in need of this friendship. Yet, no one can foresee today what tomorrow will bring. It may be shattered and shrink just like the Ottoman Empire, just like the Austrian-Hungarian Empire. Nations which it holds in its hand very tightly today may get loose. The world may reach a new balance. Now then, Turkey should be able to know what to do... We have brothers of one language, one faith and one origin under the administration of this friend of ours. We need to be prepared to look out for them. Being prepared is not all about remaining quiet and waiting for that day. It is necessary to get ready. How nations can get ready for this? By keeping the spiritual bridges strong, Language is a bridge; faith is a bridge; history is a bridge. We need to go deep into our origins and commune with each other within the very history split by the events. We should not wait for them (the Turks Abroad) to get closer to us. We should get closer to them" Karal [42] emphasized the importance of the Turkic World and showed that this geography needed to become known. Hence, every Turkish child should learn about the history and culture our consanguineous ones who live outside our borders and be able to play a role in the development of relationships to be established with those countries.

\section{Methods}

\subsection{Purpose of the Research}

The research aims at revealing pre-service teachers' cognitive structure regarding the Turkic world and independent Turkic states through the Word Association Test (WAT), which is an alternative assessment technique.

\subsection{Research Design}

The study was conducted as a descriptive research in the survey model. Survey models are the research approaches aiming to describe a past or current event as it is stated by Karasar [43]. 


\subsection{Study Group}

The study group was composed of 332 pre-service teachers who were attending at the programs of Elementary Teaching, Social Studies Teaching, Science Teaching, Turkish Language Teaching and History Teaching (pedagogical formation) in the Faculty of Education of Niğde University. Personal information of the students in the study group is given in Table 1 .

Table 1. Personal Information of the Students in the Study Group

\begin{tabular}{|l|c|}
\hline Department & f \\
\hline Social Studies Teaching & 123 \\
\hline Elementary Teaching & 100 \\
\hline Turkish Language Teaching & 43 \\
\hline History Teaching (pedagogical formation) & 43 \\
\hline Science Teaching & 23 \\
\hline Total & 332 \\
\hline
\end{tabular}

\subsection{Data Collection Instrument}

The WAT seen in Table 2 was used as the data collection instrument in the research. To create the test, the key concept was chosen to be the Turkic world which refers to independent Turkic states (Azerbaijan, Kazakhstan, Kyrgyzstan, and Turkish Republic of Northern Cyprus, Turkmenistan and Uzbekistan) and a general framework of the Turkic world.

Before starting to apply the test, explanations for the WAT were made and examples of different applications were provided. The students were given a duration of one minute for each concept. The students wrote the response words which they thought were related to the key concept across those concepts.
Table 2. WAT Draft Applied To Teacher Candidates

\begin{tabular}{|l|l|l|l|l|}
\hline Kazakhstan & & & Azerbaijan & \\
\hline Kazakhstan & & & Azerbaijan & \\
\hline Kazakhstan & & & Azerbaijan & \\
\hline Kazakhstan & & & Azerbaijan & \\
\hline Kazakhstan & & & Azerbaijan & \\
\hline Kazakhstan & & & Azerbaijan & \\
\hline Kazakhstan & & & Azerbaijan & \\
\hline Kazakhstan & & & Azerbaijan & \\
\hline Kazakhstan & & & Azerbaijan & \\
\hline
\end{tabular}

\subsection{Analysis of Data}

The response words given to the key concepts were examined in detail to evaluate the WAT students. A frequency table was prepared to show how many times, and which words or concepts were repeated in response to a key concept. A concept map was created on the basis of this frequency table. The breakpoint (BP) technique suggested by Bahar, Johnstone and Sutcliffe [2] was used in creating the concept map so that it can show the relationships between the concepts in the cognitive structure.

\section{Findings}

The concept map was created on the basis of the frequency table and the cognitive structure of the students is shown as follows.

The results seen in the concept map can be interpreted as below:

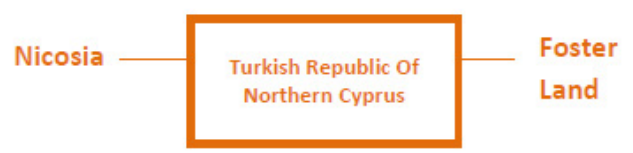

Figure 1. Breakpoint 150 and above 
Breakpoint 150 and above: the word "Baku" was associated with Azerbaijan; the word foster land was associated with the Turkish Republic of Northern Cyprus (T.R.N.C) and Nicosia within this range This indicates that the best known countries in students' minds are Azerbaijan and the T.R.N.C and the students have the capitals and the expression of the "foster land" commonly used in our country for the Northern Cyprus. Within this range, there was no word associated with Kazakhstan, Kyrgyzstan, Uzbekistan, Turkmenistan and the Turkic world.

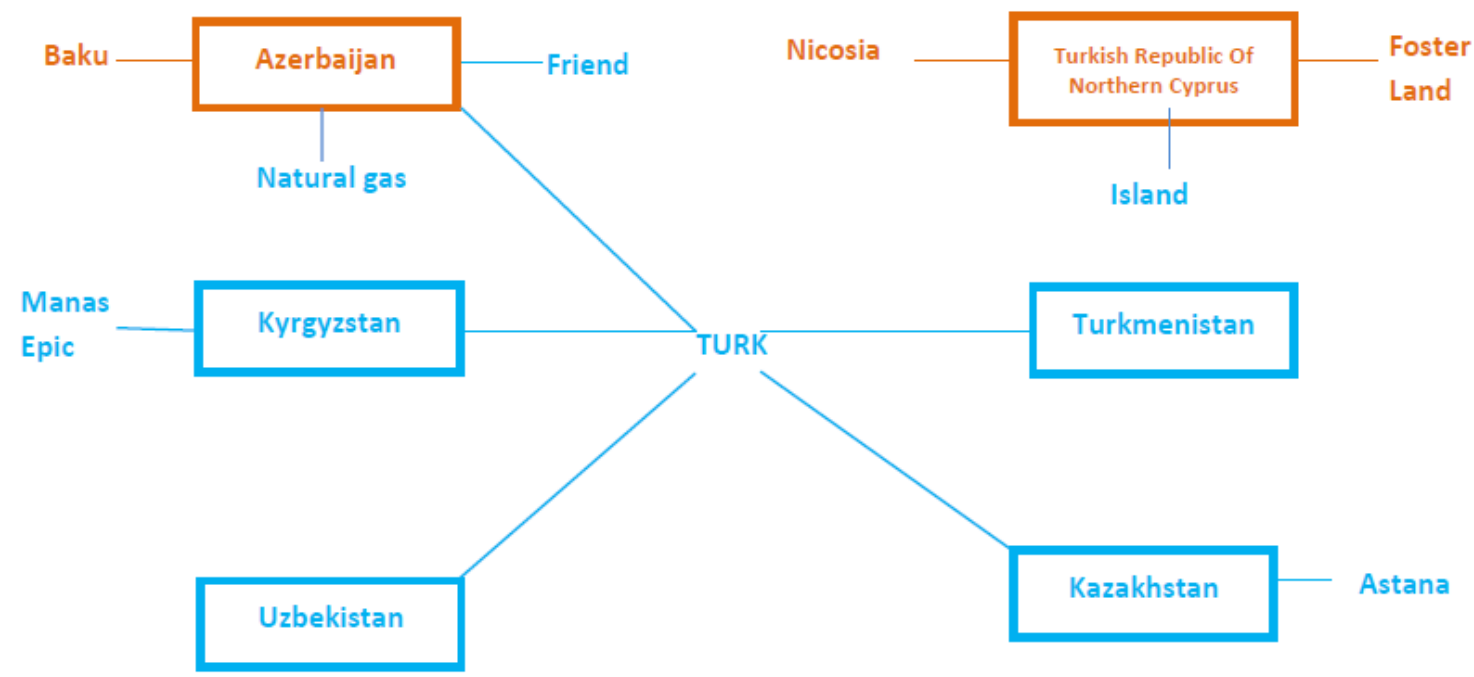

Figure 2. Breakpoint 100 to 149

Breakpoint 100 to 149: other Turkic states appeared and the word "Turk" was appeared to be a common word within this range. Other than the common word "Turk", there was no common word for these countries within this range but the word "Astana" was associated with Kazakhstan, the word "Manas", the national epic, was associated with Kyrgyzstan; the words friend/brother country and natural gas were associated with Azerbaijan; and the word "island" was associated with the T.R.N.C.

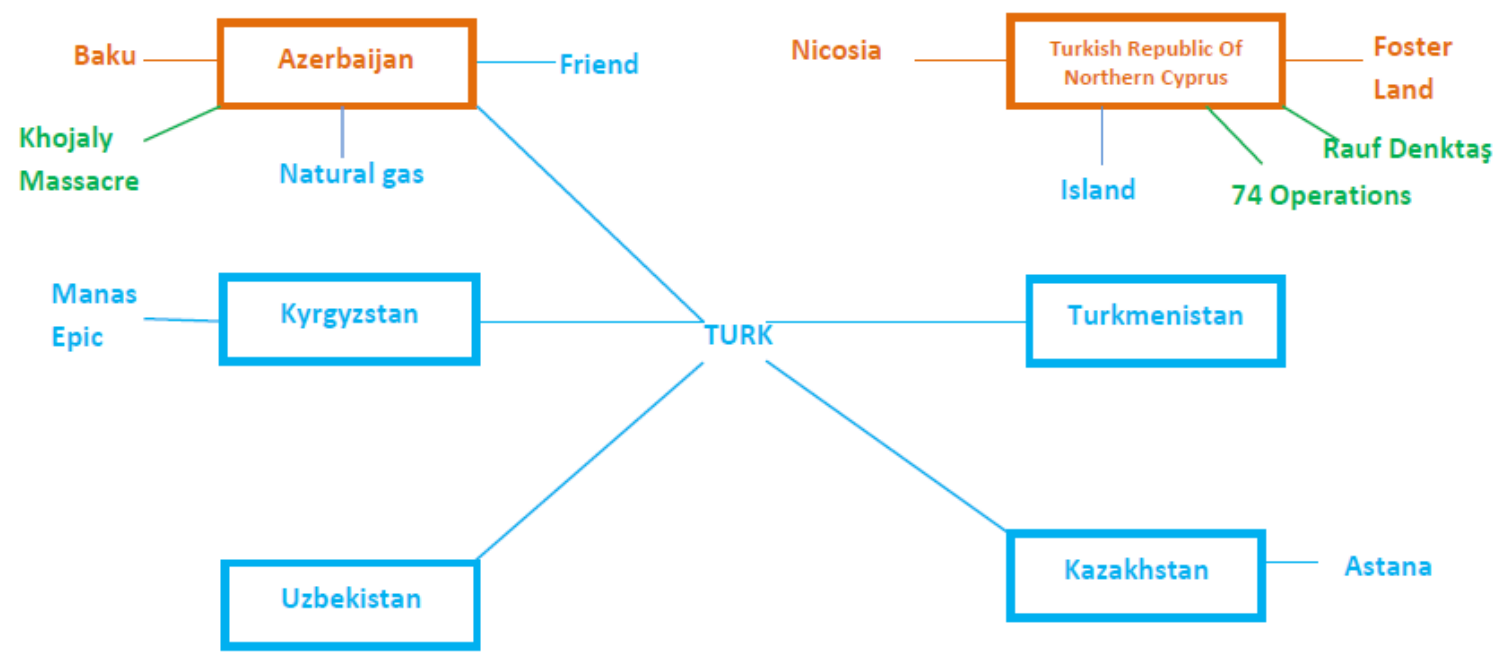

Figure 3. Breakpoint 80 to 99

Breakpoint 80 to 99: there were associations only for Azerbaijan and the T.R.N.C within this range, and those associations were rather about current and general events in those countries. Within this range, the words Khojaly Massacre by Armenians on Azerbaijan appeared while the words Cyprus Peace Operation and the statesman Rauf Denktaş, who is the founder president and long-time administrator, were associated with the T.R.N.C. Other than the word "Turk", no common concept appeared in students' minds within this range, and countries were perceived in a structure far from any relationship. 


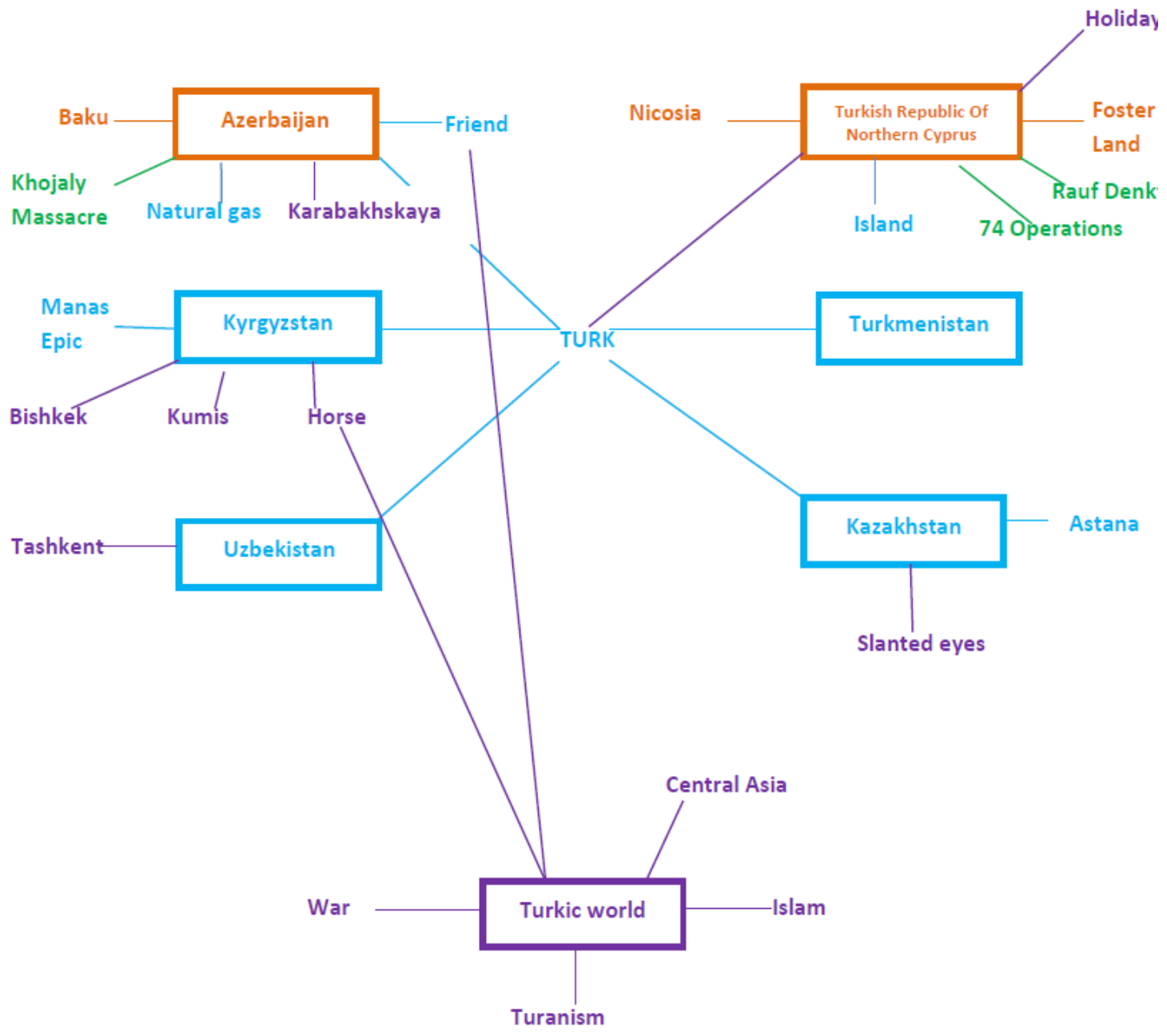

Figure 4. Breakpoint 60 to 79

Breakpoint 60 to 79: The relationship words regarding the concept of the "Turkic world" first appeared within this range. The students associated the words Central Asia, Islam, Turanism, war and horse with the Turkic world. The word horse appeared as a common word for the Turkic world and Kyrgyzstan within this range. Other associations which appeared within this range are the word slanted eyes for Kazakhstan, the capital Tashkent for Uzbekistan, the capital Bishkek and the word kumis for Kyrgyzstan, Karabakhskaya for Azerbaijan and holiday destination for the T.R.N.C. The pre-service teachers established connections between the Turkic world and the words friend/brother and the T.R.N.C and the word Turk within this range. It is seen that even within the range of 76-60, there were not many common words in students' cognitive perceptions and they could not make a connection between the countries and the concept of Turkic world. The common word for all the countries given within this range was the word "Turk". 


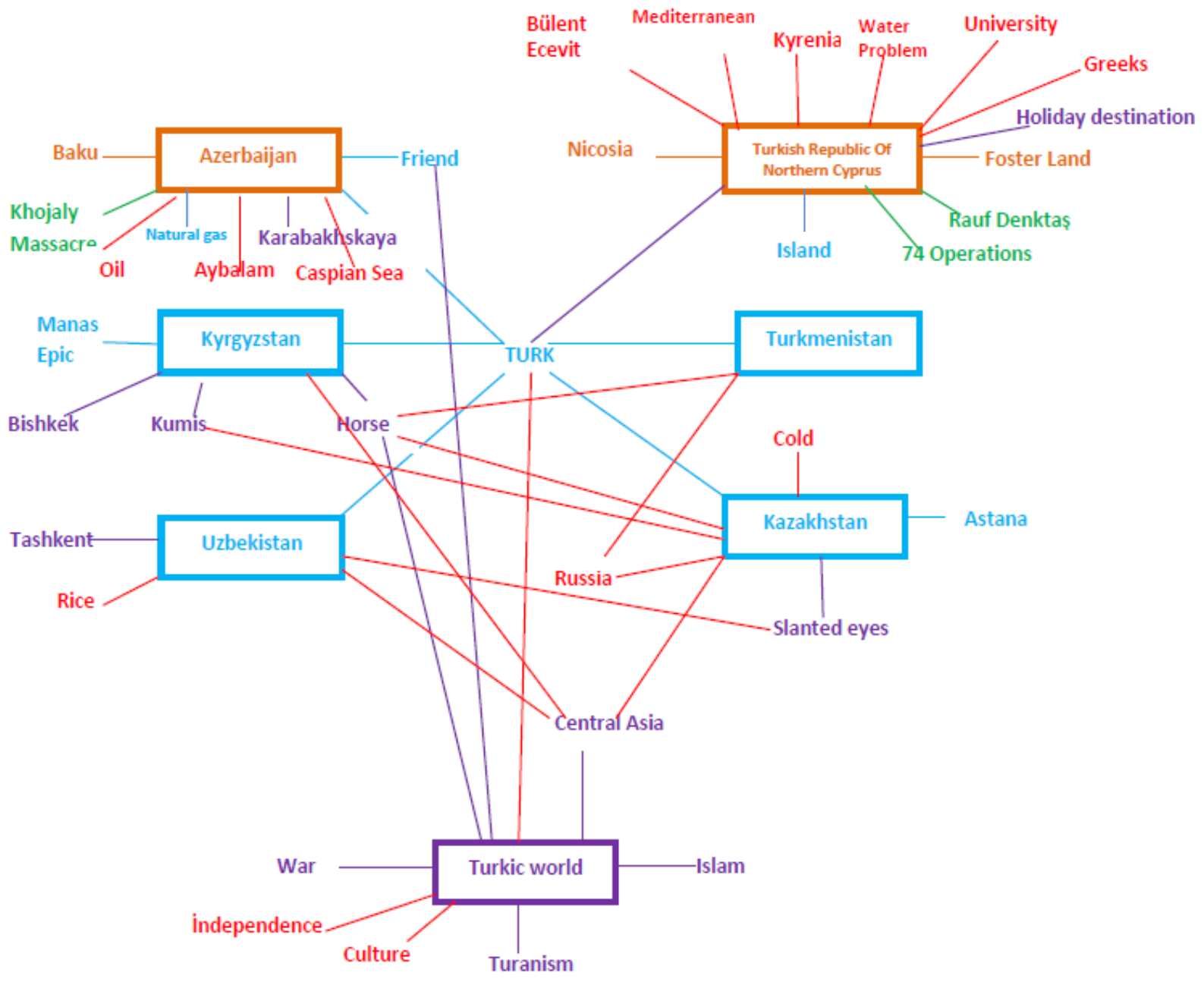

Figure 5. Breakpoint 40 to 59

Breakpoint 40 to 59: Within this range, it is seen that the relationship between the concept of the Turkic world and the word Turk emerged and the only common perception was the word "Turk" for all the concepts given, that is, for both independent Turkic states and the Turkic world. Again, within this range, the concepts which appeared as common words were Central Asia (Kazakhstan, Kyrgyzstan and Uzbekistan); Russia (Kazakhstan-Turkmenistan) and the word horse, which appeared for Kyrgyzstan before, now for Turkmenistan and Kazakhstan; kumis for Kazakhstan; and the concept of slanted eyes, which appeared for Kazakhstan before, turned into a word of common perception now for Kyrgyzstan and Uzbekistan. Within this range, no concept was able to be found to connect Azerbaijan and the T.R.N.C. with other countries, concepts such as petroleum, aybalam (beautiful kid in Azeri Turkic language) and the Caspian for Azerbaijan and Bülent Ecevit, the Mediterranean, Kyrenia, water problem, university and Greek Cypriots for the T.R.N.C. appeared in students' perceptions. The T.R.N.C. is in a position, again, away from other countries and the concept of the Turkic world within this range. The students associated Uzbekistan with pilaf; Kazakhstan with cold weather; and the Turkic world with concepts of culture and independence within this range. 


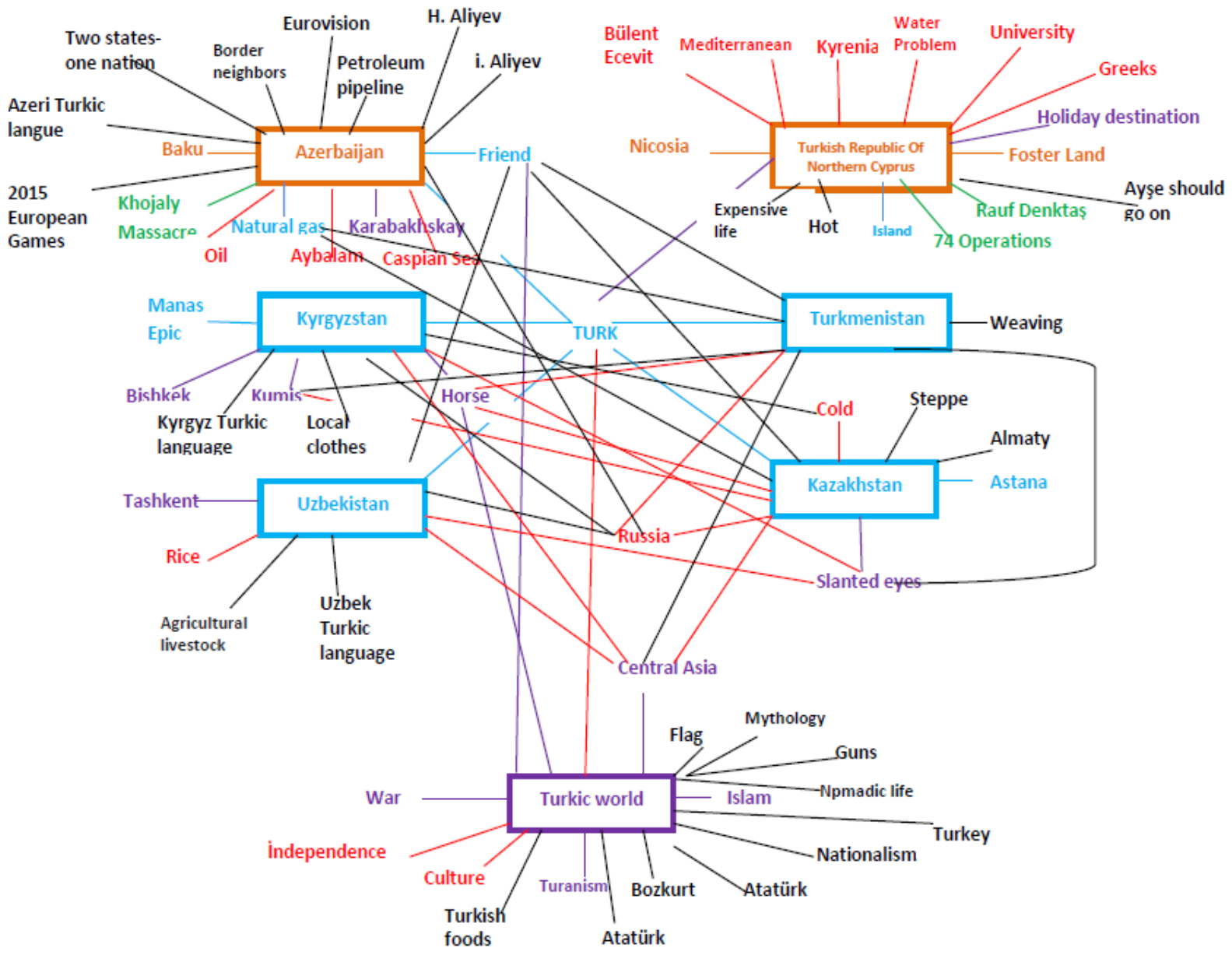

Figure 6. Breakpoint 20 to 39

Breakpoint 20 to 39: The number of common perceptions in students' minds for the Turkic states and the Turkic world increased within this range. The concept of friend/brother, which had been associated with Azerbaijan and the Turkic world before, was associated with Uzbekistan and Kazakhstan within this range but not with Kyrgyzstan and the T.R.N.C. Russia, for which students had made a connection with Kazakhstan and Turkmenistan before, was associated with Azerbaijan and Uzbekistan, and it was virtually a common perception that these states were separated from Russia to declare independence. The concept of natural gas, which is one of the most important energy sources in the region and had been associated with Azerbaijan, was associated Turkmenistan and Kazakhstan within this range. In addition, there were common associations with Central Asia and the concept of slanted eyes for Turkmenistan and the concept of cold weather for Kyrgyzstan. The response words given other than the abovementioned appeared in the new associations with every country. The students made mental connections between the state of Azerbaijan and the 2015 European Games and Eurovision, Azeri Turkic language, the motto "two states-one nation", border neighbors, petroleum pipeline, and Haydar Aliyev and İlham Aliyev, the two important leaders of the country. The T.R.N.C. was associated with the concepts of hot weather as the characteristic of the island, expensive life and the code "Ayşe should go on vacation", which commenced the Cyprus Peace Operation. There were associations between Kyrgyzstan and the Kyrgyz Turkic language and local clothes; Turkmenistan and weaving; Uzbekistan and the Uzbek Turkic language and agriculture/livestock; and Kazakhstan and steppes and Almaty. Within this range, no concept appeared to connect the concept of the Turkic world with other countries, a connection was established between the Turkic world and the concept of Turkish food, bozkurt (the sacred, mythological Turkish wolf), Atatürk, Nationalism, Turkey, nomadic life, guns, mythology, Turkish foods and flag.

\section{Conclusions and Discussion}

The relationships between the concepts in pre-service teachers' cognitive structures regarding the Turkic world were examined by the word association test (WAT) in this study. The following results were achieved at the end of the study:

The only common word associated with six independent Turkic states given to the students and the concept of the Turkic world was the concept of "Turk." Other than this, 
there was no concept perceived commonly by the pre-service teachers. The second most frequently associated word was friend/brother. This concept was associated with Azerbaijan, Turkmenistan, Uzbekistan, Kazakhstan, and the Turkic world but not with Kyrgyzstan and the T.R.N.C.

Russia was the common concept for Azerbaijan, Turkmenistan, Kazakhstan, Uzbekistan, and Kyrgyzstan which gained their independences from Russia. The concept of Central Asia was a common word associated with Kazakhstan, Turkmenistan, Uzbekistan, and Kyrgyzstan, which are Central Asian countries, and the Turkic world. Again, there was an association between the concept of slanted eyes and Kazakhstan, Turkmenistan, Uzbekistan, and Kyrgyzstan. On the other hand, horse (Kyrgyzstan, Turkic world, Kazakhstan), natural gas (Azerbaijan, Turkmenistan, Kazakhstan), kumis (Kyrgyzstan, Kazakhstan), and cold weather (Kygrgyzstan, Kazakhstan) were the common words associated with the countries.

It can be concluded from these results that the students did not have much knowledge/perception of independent Turkic states and the Turkic world in general and they knew concepts of popular culture and did not know concepts or people specific to the countries. These results coincide with the results of the studies performed by Alim [34], Aksoy and Karaçalı [35], Topal and Sezer [36], and Taşkaya [41] on the Turkic world.

The most unrelated and disconnected country was the T.R.N.C. among independent Turkic states. The only connection was the word "Turk" between the T.R.N.C. and other countries.

The country for which the students had the most perceptional concept was Azerbaijan while it was Uzbekistan for which they had the least perceptional concept. The primary reason for this may be that Azerbaijan is our direct border neighbor, it has a dialect closer to ours; the Nagorno-Karabakhskaya conflict which Azerbaijan has with Armenia. Again, the developing economic relations between the two countries after the independence and people are aware of the motto "two states-one nation", which was developed under the administrations of Elchibey, Haydar Aliyev, and İlham Aliyev can be considered to have positive impact on the awareness of the Azeri flag and capital. The reason why the Uzbek flag and capital is little known may be explained by the fact that the bilateral relations diminished as a result of the tension occurred in 1990s between the two countries. It can be said that the recognition of Uzbekistan mitigated in Turkey because the number of reports on that country decreased in the press and media, therefore affecting the awareness of flag and capital.

As a result of the WAT applied and the findings obtained, the following recommendations can be made:

WAT, which has been rather used in different branches in the field of sciences, can be used as an alternative assessment-evaluation tool in social sciences as in this study.

Students' conceptual changes can be identified by using WAT, which was used as a single application for identifying a current situation since this study was designed in the survey model, as a pretest and posttest in different models.

The subject of this study is Turkish world perceptions. Accordingly, studies can be conducted for the usability of word association tests regarding different subjects in social studies.

\section{REFERENCES}

[1] Ministry of National Education, (2005). Elementary science and technology course (4th and 5th grade) curriculum Ankara: National Education Printing House.

[2] Bahar, M., Johnstone, A.H. \& Sutcliffe, R.G. (1999). "Investigation of students' cognitive structure in elementary genetics through word association tests". Journal of Biological Education, 33, 134-141.

[3] Bahar, M. \& Özatl1, N.S. (2003). "Kelime ilişkilendirme Yöntemi ile lise 1. sınıf öğrencilerinin canlıların temel bileşenleri konusundaki bilişsel yapılarının araștırılması". Ballkesir Üniversitesi Fen Bilimleri Dergisi, 5(1), 75-85.

[4] Özatlı, N.S. \& Bahar, M. (2010). Öğrencilerin Boşaltım Sistemi Konusundaki Bilişsel Yapılarının Yeni Teknikler ile Ortaya Konmas1, Abant İzzet Baysal Üniv. Dergisi, 10 (2), 9-26.

[5] Schizas, D., Katrana, E., \& Stamou, G. (2013). Introducing Network Analysis into Science Education: Methodological Research Examining Secondary School Students' Understanding of 'Decomposition'. International Journal of Environmental and Science Education, 8(1), 175-198.

[6] Güneş, M. H. \& Gözüm, A.İ.C. (2013). İlköğretimde işlenen ekoloji konusunun 10. sınıf öğrencilerin ekosistem ekolojisi konusundaki hazırbulunuşluk düzeyleri üzerindeki etkisinin saptanmasında kelime ilişkilendirmenin kullanılması. Ĕgitim ve Öğretim Araștırmaları Dergisi, 2(3), 252-264.

[7] Kırtak, V.N. (2010). Fizik, kimya ve biyoloji öğretmen adaylarının termodinamik yasalarını günlük hayatla ve çevre sorunları ile ilișkilendirme düzeyleri. Yayımlamamıș yüksek lisans tezi, balıkesir üniversitesi fen bilimleri enstitüsü, Balıkesir.

[8] Iş1klı, M., Taşdere, A. \& Göz, N.M. (2011). Kelime ilişkilendirme testi aracılığıyla öğretmen adaylarının atatürk ilkelerine yönelik bilişsel yapılarının incelenmesi. Uşak Üniversitesi Sosyal Bilimler Dergisi, 4(1), 50-72.

[9] Bahar, M., Nartgün, Z., Durmuş, S. \& Bıçak, B. (2014). Geleneksel-tamamlayıcı ölçme ve değerlendirme teknikleri. Ankara: Pegem Akademi.

[10] Cardellini, L. \& Bahar, M. (2000). Monitoring the learning of chemistry through word association tests. Australian Chemistry Resource Book, 19, 59-69.

[11] Köseoğlu, F., \& Bayır, E. (2011). Kelime İlişkilendirme Test Yöntemiyle Kimya Öğretmen Adaylarının Gravimetrik Analize İlişkin Bilişsel Yapılarının İncelenmesi.Trakya Üniversitesi Eğitim Fakültesi Dergisi, 1(1), 107-125. 
[12] Polat, G. (2013). 9. Sınıf Öğrencilerinin Çevreye İlișkin Bilişsel Yapılarının Kelime İlişkilendirme Test Tekniği ile Tespiti.Necatibey Ĕgitim Fakültesi Elektronik Fen ve Matematik Ĕ̈itimi Dergisi, 7(1), 97-120.

[13] Şimsek, M. (2013). Sosyal bilgiler öğretmen adayların coğrafi bilgi sistemleri (cbs) konusundaki bilişsel yapılarının ve alternatif kavramlarının kelime ilişkilendirmesi testi ile belirlenmesi, Researcher: Social Science Studies 1(1), 64-75.

[14] Kurt, H. (2013). Biology Student Teacherse Cognitive Structure about "Living Thing". Educational Research and Reviews, 8 (12), 871-880.

[15] Kurt, H., \& Ekici, G. (2013). Biyoloji öğretmen adaylarının bağımsız kelime ilişkilendirme testi ve çizme-yazma tekniğiyle "osmoz" kavramı konusundaki bilişsel yapılarının belirlenmesi. Turkish Studies-International Periodical for the Languages, Literature and History of Turkish or Turkic, 8(12), 809-829.

[16] Kurt, H., Ekici, G., Aktas, M., \& Aksu, Ö. (2013a). On the concept" Microscope": Biology student teachers' cognitive structure.Educational Research and Reviews, 8(19), 1859-1874.

[17] Kurt, H., Ekici, G., Aktas, M., \& Aksu, Ö. (2013b). On the concept of" Respiration": Biology student teachers' cognitive structures and alternative conceptions. Educational Research and Reviews, 8(21), 2101-2121.

[18] Aydemir, A. (2014). Ortaokul 7.sınıf öğrencilerinin beşeri coğrafya kavramlarına ilişkin algılarının kelime ilişkilendirme testi aracılığıyla incelenmesi. Yayımlamamış yüksek lisans tezi, Gazi üniversitesi eğitim bilimleri enstitüsü, Ankara.

[19] Eren, F., Sahin, I., Celik, I., \& Akturk, A. O. (2014). Analysis of Secondary School Students' Perceptions about Information Technologies through a Word Association Test. Online Submission, 8(8), 2512-2515.

[20] Özata Yücel, E. \& Özkan, M. (2014). Fen Bilimleri Öğretmen Adaylarının Çevre Algılarının Kelime İlişkilendirme Aracılığıla Belirlenmesi/Determining the Environmental Perceptions of Pre-Service Science Teachers through Word Association. E-International Journal of Educational Research, 5(4), 41-56.

[21] Özata Yücel, E. \& Özkan, M. (2015). Determination of secondary school students' cognitive structure, and misconception in ecological concepts through word association test. Educational Research and Reviews, 10(5), 660-674.

[22] Atabek-Yigit, E. (2015). Exploring the relationship between cognitive structure outcomes and test achievements of pre-service science teachers on chemical bonding via flow mapping. Journal of Baltic Science Education, 14(4), 524-534.

[23] Tokcan, H. \& Topkaya, Y. (2016). Öğretmen Adaylarının Ortadoğu Algısının Kelime İlişkilendirme Testi Aracılığıyla İncelenmesi (Kilis ve Niğde Örneği). 15th International Classroom Teacher Symposium, University of Muğla Sitkı Koçman, Bodrum, Muğla, 11-14 May.

[24] Yiğit, E. A. (2016). Investigating Cognitive Structures in Some Basic Chemistry Concepts via Word Association Test.İlköğretim Online, 15(4), 1385-1398.
[25] Kostova, Z., \& Radoynovska, B. (2010). Motivating students' learning using word association test and concept maps. Bulgarian Journal of Science \& Education Policy, 4(1), 62-98.

[26] Akman, O., \& Koçoğlu, E. (2016). Investigation 8th grade students secondary school cognitive structure about principles of Ataturk through word association test. Journal of Education and Training Studies,4(11), 151-162.

[27] Kaya, B., \& Aladag, C. (2016). Determining the Cognitive Structures of Geography Teacher Candidates on "Earthquake". International Education Studies, 10(1), 122-136.

[28] Ersanli, C. Y. (2016). Investigation of Pre-Service English Language Teachers' Cognitive Structures about Some Key Concepts in Approaches and Methods in Language Teaching Course through Word Association Test. Journal of Language and Linguistic Studies, 12(1), 124-136.

[29] Armagan, F. O. (2015). Cognitive Structures of Elementary School Students: What is Science?. European Journal of Physics Education, 6(2), 54-73.

[30] Karatekin, K., Topçu, E., \& Aydınlı, B. (2016). The Determination of Cognitive Structure of Candidate Teachers about Energy Centrals. International Electronic Journal of Environmental Education, 6(2), 76-91.

[31] Higginbotham, G. (2010). Individual learner profiles from word association tests: The effect of word frequency. System, 38(3), 379-390.

[32] Tokcan,I H., Yiter, E. (2017). 5. sınıf öğrencilerinin doğal afetlere ilişkin bilişsel yapılarının kelime ilişkilendirme testi (kit) aracılığıyla incelenmesi. Ahi Evran Üniversitesi Kırşehir Eğitim Fakültesi Dergisi (KEFAD) 18(1), 115-129

[33] Ercan, F., Taşdere, A., \& Ercan, N. (2010). Kelime ilişkilendirme testi aracılığıyla bilişsel yapının ve kavramsal değişimin gözlenmesi. Türk Fen Eğitimi Dergisi (TÜFED), 7(2), 136-154.

[34] Nakiboğlu, C. (2008). Using word associations for assessing nonmajor science students' knowledge structure before and after general chemistry instruction: the case of atomic structure. Chem. Educ. Res. Pract, 9, 309-322.

[35] Alım, M. (2009). Coğrafya eğitimi öğrencilerinin Türk dünyası algıları (Atatürk Üniversitesi Örneği). Uluslararası insan bilimleri dergisi, 6(2), 574-586.

[36] Aksoy, B. \& Karaçalı, H. (2015). 7. sınıf öğrencilerinin zihin haritasında türk dünyası algısı. Uluslararası türk eğitim bilimleri dergisi, Nisan, 1-14.

[37] Topal, E. \& Sezer, A. (2016). Üniversite öğrencilerinin türk dünyasın coğrafyasına ilişkin farkındalık düzeylerinin belirlenmesi. Marmara coğrafya dergisi, 33, 96-113.

[38] Tunçel, H. (2002). Türk öğrencilerin zihin haritalarinda islam ülkeleri. Firat University Journal of Social Science 12(2), 83-103.

[39] Bilgiç, S. \& Akyürek, S. (2012). Balkanlarda türkiye ve türk algısı. İstanbul: BİLGESAM

[40] Alkan, M.N. (2013).Türkiye'deki üniversite öğrencilerinin avrupa birliği algısl, Ankara: Konrad-adenauer-stiftung e.V.

[41] Taşkaya, S.M. (2014). Sınıf öğretmeni adaylarının türk dünyas1 algis1. Researcher: Social Science Studies, 2, 44-55. 
[42] Karal, E.Z. (2003). Atatürk'ten düşünceler. Ankara: ODTÜ yayıncilık
[43] Karasar, N. (1999), Bilimsel araștırma yöntemi. Ankara: Nobel Yayın Dağıtım.

i This article was presented at 3rd International Dynamic, Exploratory and Active Learning Conference (IDEAL 2016) oral presentation. 